\title{
Effect of fruit load of the first coffee harvests on leaf gas exchange ${ }^{1}$
}

\author{
Carlos Andres Unigarro Muñoz ${ }^{2}$, Lina Marcela Díaz Bejarano ${ }^{3}$, José Ricardo Acuña ${ }^{2}$
}

\section{ABSTRACT}

Coffee production between the first and second harvest presents a difference in the fruit load with the plant age that could affect the leaf gas exchange. This research aimed to evaluate the effect of the increase in fruit load that occurs between the first and second harvest of the Coffea arabica L. production cycle on the measured gas exchange, at the two phenological stages of the fruit. The accessions E057, E318, E338 and E554 were used, as well as a completely randomized design, with three replications, using the accessions as treatments and the harvest measurements during the production cycle as the repeated measures. The variables yield per tree, number of fruits, absolute growth rates for height and stem, leaf area, leaf-to-fruit ratio and leaf gas exchange were measured across the phenological stages of fruit filling and ripening. The increase in the fruit load that occurs with age in the second harvest, if compared to the first harvest, showed a positive and significant effect on the net assimilation rate that was not expected for the obtained leaf-tofruit ratios. Likewise, the differences in the assimilation rates were higher during the fruit-filling stage. This result suggests that the source-sink relationship may vary with the crop age and fruit phenological stage, and is not entirely depend on the leaf-to-fruit ratio.

KEYWORDS: Coffea arabica L., leaf-to-fruit ratio, fruit phenological stage, net assimilation rate.

\section{INTRODUCTION}

Coffee is the second most traded commodity in the world after oil, and its cultivation constitutes a source of income for 26 million people in 56 countries (Davis et al. 2012, Castro-Tanzi et al. 2014). In Colombia, the area dedicated to the commercial cultivation of Arabic coffee is 911 thousand hectares, with varieties resistant to rust grown in $76.3 \%$ of the territory (FNC 2017). In contrast, the commercial

\section{RESUMO}

Efeito da carga de frutos das primeiras colheitas de café na troca gasosa das folhas

A produção de café entre a primeira e segunda colheita apresenta diferença na carga dos frutos com a idade da planta, podendo ter efeito na troca gasosa. Objetivou-se avaliar o efeito do aumento na carga de frutos que acontece entre a primeira e a segunda colheita do ciclo produtivo do Coffea arabica L. na avaliação da troca gasosa, no decorrer dos dois estados fenológicos do fruto. Foram utilizados os acessos E057, E318, E338 e E554, bem como delineamento inteiramente casualizado, com três repetições, tendose os acessos como tratamentos e as medições de colheita do ciclo produtivo como medidas repetidas. As variáveis produtividade por planta, número de frutos, taxas de crescimento absoluto de altura e tronco, área foliar, relação folha-fruto e trocas gasosas da folha foram medidas nas fases fenológicas de enchimento e maturação dos frutos. O aumento da carga de frutos que ocorre com a idade na segunda colheita, em relação à primeira, apresentou efeito positivo e significativo na taxa de assimilação líquida, o qual não era esperado para as relações folha-fruto obtidas. Da mesma forma, as diferenças nas taxas de assimilação foram maiores durante a fase de enchimento dos frutos. Isso sugere que a relação fonte-dreno pode variar com a idade de cultivo e estádio fenológico do fruto, e não depende totalmente da relação folha-fruto.

PALAVRAS-CHAVE: Coffee arabica L., relação folha-fruto, estádio fenológico do fruto, taxa de assimilação líquida.

production of canephora coffees in the country is incipient and limited to investigative, experimental lots.

In fruit trees such as mango (Urban et al. 2004), citrus (Rivas et al. 2007), peach (Duan et al. 2008) and coffee (Franck et al. 2006, Vaast et al. 2006), the fruit load (sink) affects the production of dry matter, carbon partitioning and leaf photosynthetic activity (source). In this context, by reducing the sink demand for carbohydrates, there is a decrease in the net photosynthetic rate, mainly in response to the

${ }^{1}$ Received: Aug. 04, 2021. Accepted: Oct. 08, 2021. Published: Nov. 16, 2021. DOI: 10.1590/1983-40632021v5169865.

${ }^{2}$ Centro Nacional de Investigaciones de Café (Cenicafé), Disciplina de Fisiología Vegetal, Manizales, Colombia.

E-mail/ORCID: andresunigarro@gmail.com/0000-0002-7344-3211; ricardo.acuna@cafedecolombia.com/0000-0001-6935-2264.

${ }^{3}$ Pontificia Universidad Javeriana, Centro de Estudios Interculturales, Cali, Colombia.

E-mail/ORCID: linadiazbejar@gmail.com/0000-0003-1967-4139. 
accumulation of products in the leaves, which, by not translocating, restricts the net photosynthetic rate (Morais et al. 2012). In contrast, under a high fruit load, the demand for carbohydrates increases and, with it, the translocation of the products in the leaves, thus avoiding the limitation of the photosynthesis rate (Vaast et al. 2002). Nevertheless, in trees such as palm (Zhen et al. 2019) and macadamia (Smit et al. 2020), it has been reported that the net photosynthetic rate can be upregulated when the strength of the sink is increased by increasing the stomatal conductance, and not by a feedback effect. The latter is the case for Coffee arabica, for which there is evidence of coordination between the source and sink, but the photosynthetic rate is not mediated by the accumulation of carbohydrates in the leaves.

Cannell (1971) observed an increase of around $30 \%$ in the photosynthetic rate when the trees retained all their fruits, if compared to those in which the fruits were removed from. Vaast et al. (2005) found that in ring-barked branches with $100 \%$ of fruits, the photosynthetic rate was 2.6 times higher than in ring-barked branches without fruits. Ronchi et al. (2006) showed that the concentrations of sucrose, hexoses and starch were not associated with the photosynthesis rate. On the other hand, DaMatta et al. (2008) found that the reduction in the photosynthetic rate is independent of the accumulation of nonstructural carbohydrates in the leaves and the lower capacity of mesophilic cells to fix carbon; however, the photosynthetic rate was coupled to changes in stomatal conductance when the source-sink relationship was manipulated. Recently, Avila et al. (2020) found that coffee leaves can accumulate relatively large amounts of starch without showing a marked downregulation of photosynthesis, and that the photosynthetic rate was mainly limited by diffusive factors when leaf-to-fruit ratios were high (low fruit loads). Almeida et al. (2021) showed that a high fruit load causes a feedforward effect on the photosynthesis rate, which is coupled with increased stomatal conductance but not associated with the internal concentration of $\mathrm{CO}_{2}$. In this study, the highest stomatal conductance in plants with low leaf-to-fruit ratios (high fruit loads) was associated with lower stomatal sensitivity to vapor pressure deficits at the leaf level.

The phenological stage of the fruits can also influence the source-sink relationship. According to Vaast et al. (2002), the translocation of dry matter to the fruits was greater than that destined for the growth of branches during fruit filling, since approximately $95 \%$ of the nitrogen, phosphorus and potassium absorbed by plants accumulated in fruits during this time (Cannell 1985). On the other hand, the contribution of the photosynthetic area in coffee fruits during fruit filling can cover up to $30 \%$ of the daily needs of respiration and provide $12 \%$ of the total carbon requirements (Vaast et al. 2005). Therefore, understanding the source-sink effects on the leaf photosynthesis rate is physiologically important to examine the effects of agronomic practices and their possible repercussions on the primary production of coffee (Franck et al. 2006).

The transition between the first (second year of cultivation with low load) and second (third year of cultivation with high load) harvest of the production cycle presents an increase in both the production and leaf area (Arcila \& Chaves 1995). However, since the growth of source organs relatively to sink organs is not equivalent, there could be relationships between the source and the sink that are similar to those found in experiments with manual defrutification.

Coffee production under normal growing conditions increases with the crop age (Echavarria et al. 1993), resulting in a difference in the fruit load with age, which can be very marked between the first (second year) and second (third year) harvest, in the production cycle of $C$. arabica, with an increase between 30 and $50 \%$ (Arcila et al. 2007). However, in this context, the behavior of the photosynthesis rate, stomatal conductance and internal $\mathrm{CO}_{2}$ concentration is unknown. For this reason, the present study aimed to evaluate the effect of the increase in fruit load that occurs between the first (low fruit load) and second (high fruit load) harvest of the C. arabica production cycle on the gas exchange measured during two phenological stages of the fruit.

\section{MATERIAL AND METHODS}

The experiment was conducted under field conditions at the San Antonio Experimental Station of Cenicafé, in Floridablanca (Santander, Colombia) $\left(7^{\circ} 5^{\prime} \mathrm{N}, 73^{\circ} 3^{\prime} \mathrm{W}\right.$ and $1,539 \mathrm{~m}$ of altitude). The mean annual air temperature and rainfall were $19.9^{\circ} \mathrm{C}$ and $1,559 \mathrm{~mm}$, respectively. Four semi wild accessions (E057, E318, E338 and E554) of coffee (Coffee arabica L.) with similar agronomic and productive characteristics were evaluated. 
The trees underwent pruning and were planted with $1.0 \mathrm{~m}$ between plants and $2.0 \mathrm{~m}$ between rows (population of 5,000 trees ha-1), under full sunlight conditions. In the field, three rows with ten trees were established for each accession. In every row, three trees were selected for evaluation. The soil fertilization and agronomic management of the crop were carried out under technical recommendations (Sadeghian 2014).

The agronomic variables were number of coffee fruits per tree (fruit tree ${ }^{-1}$ ) and coffee berry yield per tree $\left(\mathrm{g}\right.$ tree $\left.\mathrm{e}^{-1}\right)$, corresponding to the fruits collected during the principal harvest period, which occurs annually between August and November. The mean absolute growth rates $(\overline{\mathrm{G}})$ for stem height $\left(\overline{\mathrm{GSH}} ; \mathrm{cm} \mathrm{month}{ }^{-1}\right)$ and stem diameter ( $\overline{\mathrm{GSD}} ; \mathrm{mm}$ month $\left.^{-1}\right)$ were calculated according to equation $\overline{\mathrm{G}}=\left(\mathrm{V}_{2}-\mathrm{V}_{1}\right) /\left(\mathrm{t}_{2}-\mathrm{t}_{1}\right)$ (Hunt 1990), where $\overline{\mathrm{G}}$ is the mean absolute growth rate, $\mathrm{V}_{1}$ the value of the variable at time $t_{1}$, and $V_{2}$ the value of the variable at time $t_{2}$, using the stem height and diameter recorded in April and November every year.

For each sampled tree in each row, the total number of leaves (NLT) was counted and, in parallel, the width of each individual leaf blade was measured $\left(\mathrm{W}_{\mathrm{i}} ; \mathrm{cm}\right)$ on the leaves present on $1 / 4$ of the total branches of the stem per tree. The branches were chosen from the base of the stem to the apical meristem. Then, the size of the individual leaf (LS; $\mathrm{cm}^{2}$ ) was estimated based on $\mathrm{W}_{\mathrm{i}}$ data using the equation $\mathrm{LS}_{\mathrm{i}}=1.68938 \times \mathrm{W}_{\mathrm{i}}^{1.87577}\left(\mathrm{~N}=6,441 ; \mathrm{R}^{2}=\right.$ $0.96)$ (Unigarro et al. 2015). The leaf area per tree $\left(\mathrm{LA} ; \mathrm{m}^{2}\right)$ was estimated by multiplying the average leaf size $\left(\mathrm{LS} ; \mathrm{cm}^{2}\right)$ by the NLT of the corresponding tree using the equations $\mathrm{LS}=1 / \mathrm{n} \sum_{\mathrm{i}=1}^{\mathrm{n}} \mathrm{LS}_{\mathrm{i}}$ and $\mathrm{LA}=(\mathrm{LS} \times \mathrm{NLT}) / 10,000$. The leaf-to-fruit ratio (LFR; $\mathrm{cm}^{2}$ leaf fruit ${ }^{-1}$ ) was calculated by dividing the LA by the number of coffee fruits per tree.

The leaf physiological evaluations were carried out during two fruit phenological stages in both the first and second harvests of the crop production cycle. The first phenological stage was fruit filling, where the fruits are in the linear phase of dry matter accumulation (between April and June), with $30-70 \%$ of their final size (Arcila et al. 2002). The second phenological stage was fruit ripening, a time in which the fruits are physiologically mature (between September and November) and have reached $90 \%$ of their final size (Arcila et al. 2002).

Physiological measures of net assimilation rate $\left(\mathrm{A}_{\mathrm{n}} ; \mu \mathrm{mol} \mathrm{CO}_{2} \mathrm{~m}^{-2} \mathrm{~s}^{-1}\right)$, stomatal conductance

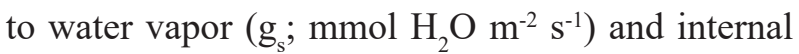
$\mathrm{CO}_{2}$ concentration, regarding the environmental $\mathrm{CO}_{2}$ concentration rate $\left(\mathrm{C}_{\mathrm{i}} / \mathrm{C}_{\mathrm{a}}\right)$, were made per sampled tree on a leaf (healthy and fully expanded) from the third or fourth node counted from the apex of the plagiotropic branch located in the middle third of the row of plants. An open system infrared gas analyzer (CIRAS-3, PP Systems, MA) was used to measure the physiological parameters between 07:00 a.m. and 10:00 a.m., under a concentration of $380 \mu \mathrm{mol}$ $\mathrm{CO}_{2} \mathrm{~m}^{-2} \mathrm{~s}^{-1}$, constant leaf temperature of $25{ }^{\circ} \mathrm{C}$ and saturating irradiance of $1,000 \mu \mathrm{mol}$ photons $\mathrm{m}^{-2} \mathrm{~s}^{-1}$ supplied by an RGBW LED light source (Light Control, PP Systems, MA). The physiological parameters $\mathrm{A}_{\mathrm{n}}, \mathrm{g}_{\mathrm{s}}$ and $\mathrm{C}_{\mathrm{i}} / \mathrm{C}_{\mathrm{a}}$ for each replication were computed as the average value.

The experiment used a completely randomized design, with three rows of each accession randomly distributed (each row corresponding to one replication). The information for each replication (experimental unit) was recorded during the first harvest of the production cycle, which corresponds to a low fruit load on the plant, and at the second harvest of the productive cycle, which corresponds to a high fruit load, with regard to the previous harvest. The first and second harvest of the production cycle corresponded to the second and third years after pruning. The data for these variables were analyzed by a mixed model, using the covariance structure of the compound symmetry (the one with the best fit, based on the Akaike information criterion) (Correa 2004). In the model, the sources of variation were "harvest load" (within-subjects factor), "accession" (between-subjects factor) and their interaction ("harvest load* accession"). Multiple comparisons for significant sources of variation were made with the Tukey test at $5 \%$ of significance. The relationships between the variables were evaluated with the Pearson's correlation coefficient (r), using the values obtained for each replication, and the significance of the Pearson's coefficients was tested with the Student's t test at 1 and $5 \%$ of significance. Statistical analyses were performed with the PROC MIXED and PROC CORR procedures of the SAS software v.9.4 (SAS Institute 2018).

\section{RESULTS AND DISCUSSION}

The variables number of fruits, yield per tree, growth rates for stem height and diameter, 
leaf-to-fruit ratio and net assimilation rate (in the fruit-filling and fruit-ripening stages) presented significant differences $(\mathrm{p}<0.05)$ under "harvest load", while the variables leaf area, $\mathrm{C}_{\mathrm{i}} / \mathrm{C}_{\mathrm{a}}$ rate and stomatal conductance (in both the fruit phenological stages) did not differ significantly $(\mathrm{p}>0.05)$ (Table 1$)$. However, none of the evaluated variables showed significance under "accession" and "harvest load * accession" ( $p>0.05)$ (Table 1). This indicates that the differences in the variables are mainly due to the effect of the harvest and its corresponding fruit load, and not the accession effect. For this reason, multiple comparisons were only made between the means at different ages for each variable (Figure 1).

The harvest effect and its link with fruit load was clearly observed in the variables number of fruits and yield per tree, with both variables being significantly lower $(p<0.05)$ in the first harvest than in the second one (54 and $39 \%$, respectively) (Figures 1A and 1B). The first harvest corresponds to the beginning of the reproductive period, and typically has a low fruit load. Then, in the second harvest, when completely entering the reproductive

Table 1. Analysis of variance for number of fruits per tree (NoFru), coffee berry yield per tree (YPT), mean absolute growth rate for stem height ( $\overline{\mathrm{GSH}})$, mean absolute growth rate for stem diameter ( $\overline{\mathrm{GSD}})$, leaf area per tree (LA), leaf-to-fruit ratio (LFR), net assimilation rate $\left(\mathrm{A}_{\mathrm{n}}\right)$, stomatal conductance to water vapor $\left(\mathrm{g}_{\mathrm{s}}\right)$ and internal $\mathrm{CO}_{2}$ concentration regarding the environmental $\mathrm{CO}_{2}$ concentration rate $\left(\mathrm{C}_{i} / \mathrm{C}_{\mathrm{a}}\right)$ of Coffea arabica L. under "harvest load", "accession" and their interaction.

\begin{tabular}{|c|c|c|c|}
\hline Items & Harvest load & Accession & Harvest load $*$ accession \\
\hline Df & 1 & 3 & 3 \\
\hline \multicolumn{4}{|c|}{ Agronomic variables } \\
\hline NoFru & $<0.0001$ & 0.4162 & 0.2742 \\
\hline YPT & 0.0003 & 0.3895 & 0.1923 \\
\hline$\overline{\mathrm{GSH}}$ & 0.0001 & 0.1349 & 0.1591 \\
\hline$\overline{G S D}$ & 0.0009 & 0.2535 & 0.1692 \\
\hline LA & 0.0836 & 0.8721 & 0.2225 \\
\hline LFR & 0.0002 & 0.1257 & 0.2268 \\
\hline \multicolumn{4}{|c|}{ Leaf physiological variables - fruit-filling stage } \\
\hline$A_{n}$ & 0.0002 & 0.0768 & 0.0967 \\
\hline $\mathrm{C}_{\mathrm{i}} / \mathrm{C}_{\mathrm{a}}$ & 0.1650 & 0.8469 & 0.4260 \\
\hline$g_{s}$ & 0.0988 & 0.4484 & 0.5044 \\
\hline \multicolumn{4}{|c|}{ Leaf physiological variables - fruit-ripening stage } \\
\hline$A_{n}$ & 0.0021 & 0.4897 & 0.4585 \\
\hline $\mathrm{C}_{\mathrm{i}} / \mathrm{C}_{\mathrm{a}}$ & 0.1615 & 0.5075 & 0.1777 \\
\hline $\mathrm{g}_{\mathrm{s}}$ & 0.1366 & 0.0940 & 0.2570 \\
\hline
\end{tabular}

Df: degrees of freedom. The numbers in the table are the significance of the $F$ value $(p>F)$ with the corresponding sources of variation. period, there was a significant increase in the fruit load, when compared to the previous year.

The vegetative leaf growth represented by leaf area did not differ significantly $(\mathrm{p}>0.05)$ between harvests (Figure 1E). In established coffee crops with 5,000 trees $\mathrm{ha}^{-1}$ or more, the transition that occurs between the second and third harvest brings with it a significant increase in the fruit load (up to double), accompanied by a nonproportional increase in the plant foliage (Figure 1), under normal growth conditions, by the Colombian coffee standards (Arcila \& Chaves 1995). This situation, which occurs naturally, is similar to the manual defructification carried out in experiments testing the imbalance between the source and sink for C. arabica (Vaast et al. 2005, DaMatta et al. 2008), at least in terms of leaf-to-fruit ratio. The aforementioned result is corroborated in the present study, where the leaf-to-fruit ratio decreased significantly $(\mathrm{p}<0.05)$ by $46 \%$, during the transition toward the second harvest (Figure 1F), what is due to the lower increase in the leaf area, if compared to the increase in number of fruits (Figures $1 \mathrm{~A}$ and $1 \mathrm{E}$ ). Thus, the leaf-to-fruit ratio in the first harvest (LFR $=$ $16.0 \mathrm{~cm}^{2}$ leaf fruit ${ }^{-1}$ ) (Figure 1F) was similar to that reported in coffee trees that have been defructified with half their load (leaf surface $=100 \%$; fruits $=50 \%$ ), both at the branch $\left(17.0 \mathrm{~cm}^{2}\right.$ leaf fruit $\left.{ }^{-1}\right)$ (Vaast et al. 2005) and plant level $\left(13.4 \mathrm{~cm}^{2}\right.$ leaf fruit $\left.{ }^{-1}\right)$ (DaMatta et al. 2008). However, the leaf-to-fruit ratio in the second harvest $\left(8.7 \mathrm{~cm}^{2}\right.$ leaf fruit $\left.{ }^{-1}\right)$ (Figure 1F) was very close to that found in nondefructified coffee trees (leaf surface $=100 \%$; fruits $=100 \%$ ), both at the branch $\left(8.0 \mathrm{~cm}^{2}\right.$ leaf fruit $\left.{ }^{-1}\right)$ (Vaast et al. 2005) and plant level $\left(7.7 \mathrm{~cm}^{2}\right.$ leaf fruit $\left.{ }^{-1}\right)$ (DaMatta et al. 2008). This result was expected, given the fruit loads involved and their corresponding leaf areas. On the other hand, with the decrease in the leaf-to-fruit ratio during the transition from the first to the second harvest, the competition between the vegetative organs of the stem and the reproductive organs (fruits) was also evident, as seen with the significant $(p<0.05)$ decrease in the growth rates for stem height and diameter of 58 and $40 \%$, respectively, as the fruit load increased in the third year (Figures 1C and 1D). This decrease occurs because the fruit demands (the strongest sink in coffee) for carbohydrates is high, and, as a result, the translocation of carbohydrates toward the apical growth points in stems and branches is reduced (Cannell 1975, Vaast et al. 2002, DaMatta et al. 2008, Chaves et al. 2012, Bote \& Jan 2016). 
Agronomic variables

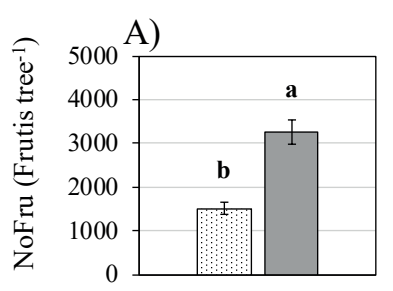

B)

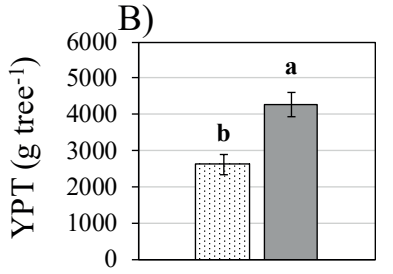

E)
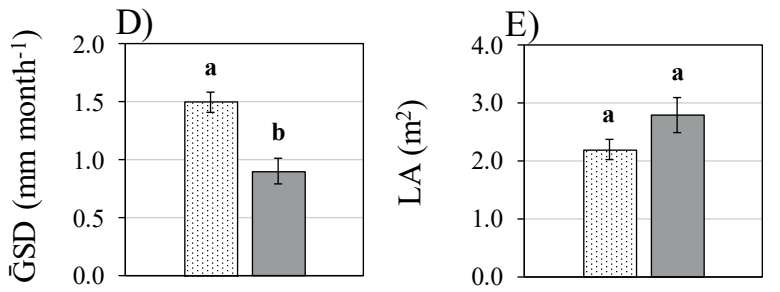
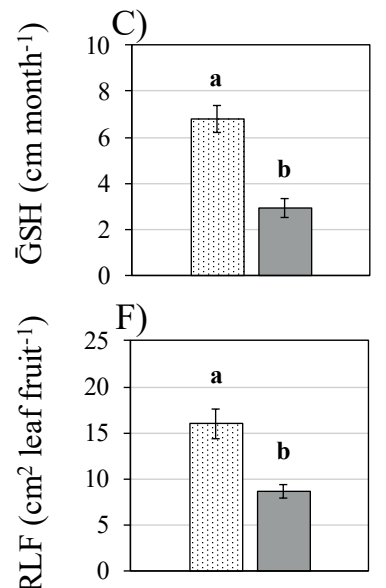

Leaf physiological variables - fruit-filling stage

G)

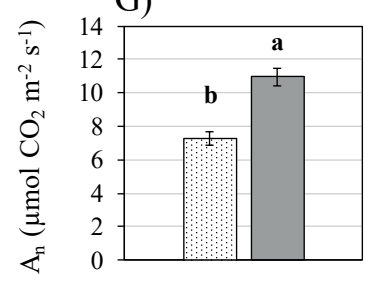

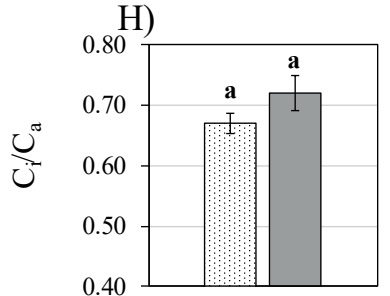

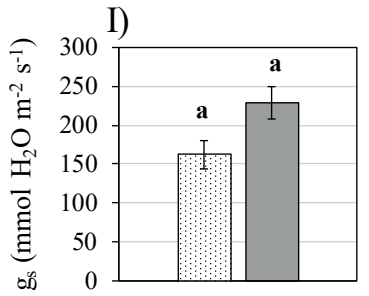

Leaf physiological variables - fruit-ripeing stage
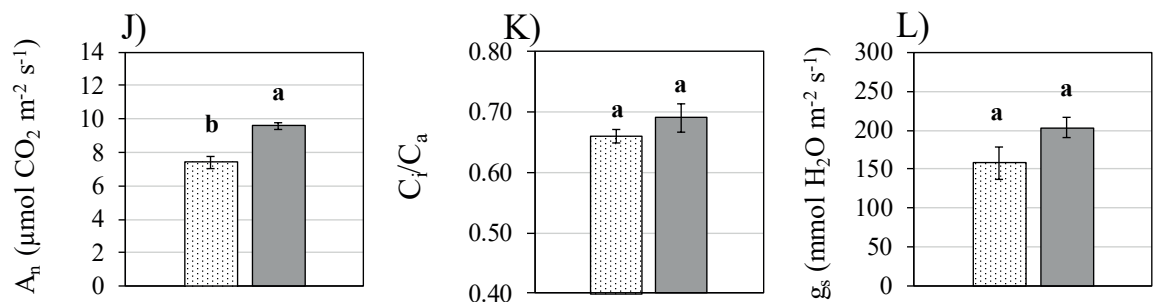

$1^{\text {st }}$ harvest - low fruit load

$2^{\text {nd }}$ harvest - high fruit load

Figure 1. Number of fruits per tree (NoFru), coffee berry yield per tree (YPT), mean absolute growth rate for stem height (ĞSH), mean absolute growth rate for stem diameter (GSD), leaf area per tree (LA), leaf-to-fruit ratio (LFR), net assimilation rate $\left(\mathrm{A}_{\mathrm{n}}\right)$, stomatal conductance to water vapor $\left(\mathrm{g}_{\mathrm{s}}\right)$ and internal $\mathrm{CO}_{2}$ concentration, regarding the environmental $\mathrm{CO}_{2}$ concentration rate $\left(\mathrm{C}_{i} / \mathrm{C}_{2}\right)$ of Coffea arabica L., based on the effects of harvest and fruit load. Different letters indicate significant differences between means using the Tukey test $(\alpha=0.05)$. Bars represent the standard error $(n=12)$.

According to the leaf-to-fruit ratio reported for coffee trees with no fruits and with fruits at half their load, both at the tree (DaMatta et al. 2008) and branch level (Vaast et al. 2005) (see the aforementioned leaf-to-fruit ratio), and given their similarity to the leaf-to-fruit ratio values found in the present study (Figure 1F), the fruit load effect was not expected to produce significant differences in the net assimilation rate or stomatal conductance. However, the data for net assimilation rate at both the fruit phenological stages show that there was a significant increase $(\mathrm{p}<0.05)$ of $23-33 \%$ associated with the fruit load of the second harvest (Figures $1 \mathrm{G}$ and $1 \mathrm{~J}$ ), which also positively affected the stomatal conductance (Figures $1 \mathrm{H}$ and $1 \mathrm{~K}$ ) and slightly affected the $\mathrm{C}_{\mathrm{i}} / \mathrm{C}_{\mathrm{a}}$ ratio (Figures $1 \mathrm{I}$ and $1 \mathrm{~L}$ ), although not significantly. This result is partially consistent with the photosynthetic behavior reported for $C$. arabica, since the increase in the fruit load has a positive effect on the net assimilation rate, mediated by stomatal conductance, but with no apparent relationship to the internal $\mathrm{CO}_{2}$ concentration (Vaast et al. 2005, DaMatta et al. 2008, Almeida et al. 2021). However, this result does not coincide with the slight 
differences expected for the net assimilation rate under the leaf-to-fruit ratio observed here.

These results suggest that the strength of the sink on the source was greater than expected for the second harvest, and, as a result, differences in the net assimilation rate were detected. Possibly, the greater strength of the sink is because, during the third year of field cultivation (second harvest), the fraction of dry matter in the fruits, when compared to the total dry matter of the plant, is one of the highest registered during the cultivation cycle (Riaño et al. 2004). This result would imply a greater pressure toward the source, due to the need of more carbohydrates, resulting in a consequent increase in the net assimilation rate. In parallel, in this period, the stem would accumulate the least amount of dry matter (Riaño et al. 2004), which could limit the reserves in the stem that the fruits might require. Another factor that could favor the differences in the net assimilation rate is the increase in the boundary layer conductance of the leaves due to the reduction in leaf size (Almeida et al. 2021), which occurs naturally with the increasing age of the crop (Arcila \& Chaves 1995). In the second harvest (third year), the leaf size was smaller $\left(35.5 \mathrm{~cm}^{2} \pm 1.4\right)$ than that obtained in the first harvest (second year) $\left(44.7 \mathrm{~cm}^{2} \pm 1.3\right)$. Almeida et al. (2021) found that the decrease in leaf size was accompanied by a higher stomatal conductance and net assimilation rate.

The fruit phenological stage also affected the net assimilation rate, since, in the second harvest, the increase in the fruit-filling stage $(11.0 \mu \mathrm{mol} \mathrm{CO}$ $\left.\mathrm{m}^{-2} \mathrm{~s}^{-1}\right)$ was $10 \%$ higher than that obtained in the fruit-ripening stage $\left(9.6 \mu \mathrm{mol} \mathrm{CO} \mathrm{m}^{-2} \mathrm{~s}^{-1}\right)$, although, in the first harvest, these values practically did not differ (7.3 and $7.4 \mu \mathrm{mol} \mathrm{CO} \mathrm{Cm}^{-2} \mathrm{~s}^{-1}$, respectively) (Figures $1 \mathrm{G}$ and $1 \mathrm{~J}$ ). Ávila et al. (2020) found that the net assimilation rate was higher during the fruit-filling than during the fruit-ripening stage for three coffee genotypes. The net assimilation rate registered during the first harvest (second year) agrees with those reported by Zhang et al. (2017) for juvenile plants (1 year) of $C$. arabica $(6-8 \mu \mathrm{mol}$ $\mathrm{CO}_{2} \mathrm{~m}^{-2} \mathrm{~s}^{-1}$ ), while the net assimilation rate from the second harvest (third year) is consistent with those observed in productive plants $\left(8.0-11.0 \mu \mathrm{mol} \mathrm{CO}_{2}\right.$ $\mathrm{m}^{-2} \mathrm{~s}^{-1}$ ) (Avila et al. 2020, Almeida et al. 2021). The stomatal conductance values for the phenological stages and years were particularly high, but they were within the range of values reported in the literature for records made between 7:00 a.m. and 11:00 a.m. (Chaves et al. 2012), the time under which the present measurements were also made.

The direct association between leaf area and yield per tree (Table 2) in coffee has been reported by Valencia (1973). On the other hand, the positive and significant relationship between yield per tree and number of fruits with the net assimilation rate during the fruit-filling and fruit-ripening stages (Table 2) indicates that, at higher fruit loads per tree, photosynthesis tends to increase in both the

Table 2. Pearson's correlation coefficients $(n=24)$ between the agronomic variables and leaf physiological variables in trees of Coffea arabica L.

\begin{tabular}{|c|c|c|c|c|c|c|c|}
\hline Variable & NoFru & YPT & $\overline{\mathrm{GSH}}$ & $\overline{G S D}$ & LA & LFR & $\mathrm{A}_{\mathrm{n}}$ \\
\hline \multicolumn{8}{|c|}{ Agronomic variables } \\
\hline YPT & $0.98^{* *}$ & & & & & & \\
\hline$\overline{\mathrm{GSH}}$ & $-0.47 *$ & -0.31 & & & & & \\
\hline$\overline{G S D}$ & $-0.41 *$ & -0.29 & $0.63 * *$ & & & & \\
\hline LA & $0.62 * *$ & $0.64 * *$ & -0.18 & -0.04 & & & \\
\hline LFR & $-0.69 * *$ & $-0.67 * *$ & 0.33 & $0.49 *$ & -0.02 & & \\
\hline \multicolumn{8}{|c|}{ Leaf physiological variables - fruit-filling stage } \\
\hline$A_{n}$ & $0.57 * *$ & $0.53 *$ & $-0.58 * *$ & $-0.69 * *$ & 0.22 & $-0.59 * *$ & \\
\hline $\mathrm{C}_{\mathrm{i}}^{\mathrm{n}} / \mathrm{C}_{\mathrm{a}}^{+}$ & 0.15 & 0.08 & -0.24 & $-0.62 * *$ & -0.11 & -0.32 & $0.41 *$ \\
\hline $\mathrm{g}_{\mathrm{s}}^{+}$ & 0.20 & 0.15 & -0.36 & -0.27 & 0.03 & -0.39 & $0.59 * *$ \\
\hline \multicolumn{8}{|c|}{ Leaf physiological variables - fruit-ripeing stage } \\
\hline$A_{n}$ & $0.61 * *$ & $0.55 * *$ & $-0.48^{*}$ & $-0.50 *$ & 0.27 & $-0.64 * *$ & \\
\hline $\mathrm{C}_{\mathrm{i}}^{\mathrm{n}} / \mathrm{C}_{\mathrm{a}}^{+}$ & $0.48^{*}$ & $0.51 *$ & -0.22 & -0.04 & 0.29 & -0.28 & 0.27 \\
\hline $\mathrm{g}_{\mathrm{s}}^{+}$ & 0.36 & 0.39 & -0.08 & -0.40 & 0.01 & $-0.64 * *$ & $0.55^{* *}$ \\
\hline
\end{tabular}

The significance of the correlation was denoted as * = significant at $95 \%(\mathrm{p}<0.05)$; ** = significant at $99 \%$ (p $<0.01)$. NoFru: number of fruits per tree; YPT: coffee berry yield per tree; ĞSH: mean absolute growth rate for stem height; $\overline{G S D}$ : mean absolute growth rate for stem diameter; LA: leaf area per tree; LFR: leaf-to-fruit ratio; $\mathrm{A}_{\mathrm{n}}$ : net assimilation rate; $\mathrm{g}_{\mathrm{s}}$ : stomatal conductance to water vapor; $\mathrm{C}_{\mathrm{i}} / \mathrm{C}_{\mathrm{a}}$ : internal $\mathrm{CO}_{2}$ concentration, regarding the environmental $\mathrm{CO} 2$ concentration rate; + : the correlation of $\mathrm{C}_{\mathrm{i}} / \mathrm{C}_{\mathrm{a}}$ and $\mathrm{g}_{\mathrm{s}}$ was carried out with the $\mathrm{A}_{\mathrm{n}}$ of their corresponding phenological stage. 
fruit phenological stages. Interestingly, correlations between the number of fruits and growth rates for stem height and diameter were significant, but no correlation was found between yield per tree and growth rates for stem height and diameter (Table 2). This result indicates that the increase in production per tree does not have a direct impact on vegetative growth reduction, which would be more associated with the increase in fruit load (Table 2).

Bote \& Jan (2016) observed that the fruit load is inversely associated with branch length and diameter. The inverse associations of the net assimilation rate with the growth rates for stem height and diameter, combined with the direct associations with the number of fruits and yield per tree (Table 2), indicates that the carbohydrates produced in the leaves were predominantly partitioned toward the fruits, especially during the fruit-filling stage (Laviola et al. 2009). Vaast et al. (2005) found that the partition of dry matter toward fruits was four times higher than that destined for branch growth over the annual production cycle, during the fruitfilling stage. The correlation between net assimilation rate and stomatal conductance was positive and moderate (Table 2), with a greater association during fruit ripening. Almeida et al. (2021) found that the relationships between net assimilation rate and stomatal conductance were significant and tended to be moderate in C. arabica. The coefficients $\mathrm{r}=-0.50$ to -0.30 and $r=0.30$ to 0.50 denote a low correlation between the variables. For the rest of the coefficients, the correlation was not significant $(p>0.05)$.

\section{CONCLUSION}

The strength of the sinks (fruits) on the sources (leaves) of Coffea arabica does not entirely depend on the leaf-to-fruit ratio, but on other factors such as crop age and fruit phenological stage. On the other hand, the carbohydrates produced in the leaves are predominantly partitioned toward the fruits.

\section{ACKNOWLEDGMENTS}

This study was funded by the Federación Nacional de Cafeteros de Colombia (FNC) and Centro Nacional de Investigaciones de Café (Cenicafé). The authors thank Carlos Roberto Ariza, Mario Franco Arcila and Mélsar Danilo Santamaría, for sharing their field experience, as well as the support staff at the San Antonio Experimental
Station, for their valuable collaboration of data recording in the field.

\section{REFERENCES}

ALMEIDA, W. L.; ÁVILA, R. T.; PÉREZ-MOLINA, J. P.; BARBOSA, M. L.; MARÇAL, D. M. S.; SOUZA, R. P. B. de; MARTINO, P. B.; CARDOSO, A. A.; MARTINS, S. C. V.; DAMATTA, F. M. The interplay between irrigation and fruiting on branch growth and mortality, gas exchange and water relations of coffee trees. Tree Physiology, v. 41, n. 1, p. 35-49, 2021.

ARCILA, J.; BUHR, L.; BLEIHOLDER, H.; HACK, H.; MEIER, U.; WICKE, H. Application of the extended $\mathrm{BBCH}$ scale for the description of the growth stages of coffee (Coffea spp.). Annals of Applied Biology, v. 141, n. 1, p. 19-27, 2002.

ARCILA, J.; CHAVES, B. Desarrollo foliar del cafeto en tres densidades de siembra. Revista Cenicafé, v. 46, n. 1, p. 5-20, 1995.

ARCILA, J.; FARFAN, F. F.; MORENO, A. M.; SALAZAR, L. F.; HINCAPIE, E. Sistemas de producción de café en Colombia. Chinchiná: FNC-Cenicafé, 2007.

ÁVILA, E. A. da S.; SOUSA, C. M.; PEREIRA, W.; MELO, H. C. de; ALMEIDA, V. G.; SARTI, J. K. Relationship of gas exchanges in different phenological phases with coffee productivity in the Cerrado. Research, Society and Development, v. 9, n. 7, e293974123, 2020.

AVILA, R. T.; MARTINS, S. C. V.; SANGLARD, L. M. V. P.; SANTOS, M. S. dos; MENEZES-SILVA, P. E.; DETMAN, K. C.; SANGLARD, M. L.; CARDOSO, A. A.; MORAIS, L. E.; VITAL, C. E.; ARAÚJO, W. L.; NUNES-NESI, A.; DAMATTA, F. M. Starch accumulation does not lead to feedback photosynthetic downregulation in girdled coffee branches under varying source-to-sink ratios. Trees, v. 34, n. 1, p. 1-16, 2020.

BOTE, A. D.; JAN, V. Branch growth dynamics, photosynthesis, yield and bean size distribution in response to fruit load manipulation in coffee trees. Trees, v. 30, n. 4, p. 1275-1285, 2016.

CANNELL, M. G. R. Production and distribution of dry matter in trees of Coffea arabica L. in Kenya as affected by seasonal climatic differences and the presence of fruits. Annals of Applied Biology, v. 67, n. 1, p. 99-120, 1971.

CANNELL, M. G. R. Crop physiological aspects of coffee bean yield: a review. Journal of Coffee Research, v. 1/2, n. 1, p. 7-20, 1975.

CANNELL, M. G. R. Physiology of the coffee crop. In: CLIFFORD, M. N.; WILLSON, K. C. (ed.). Coffee. Boston: Springer, 1985. p. 108-134. 
CASTRO-TANZI, S.; FLORES, M.; WANNER, N.; DIETSCH, T. V.; BANKS, J.; UREÑA-RETANA, N.; CHANDLER, M. Evaluation of a non-destructive sampling method and a statistical model for predicting fruit load on individual coffee (Coffea arabica) trees. Scientia Horticulturae, v. 167, n. 1, p. 117-126, 2014.

CHAVES, A. R. M.; MARTINS, S. C. V.; BATISTA, K. D.; CELIN, E. F.; DAMATTA, F. M. Varying leaf-to-fruit ratios affect branch growth and dieback, with little to no effect on photosynthesis, carbohydrate or mineral pools, in different canopy positions of field-grown coffee trees. Environmental and Experimental Botany, v. 77, n. 1, p. 207-218, 2012.

CORREA, G. A. Análisis de medidas repetidas. Medellín: Universidad Nacional de Colombia, 2004.

DAMATTA, F. M.; CUNHA, R. L.; ANTUNES, W. C.; MARTINS, S. C. V.; ARAUJO, W. L.; FERNIE, A. R.; MORAES, G. A. B. K. In field-grown coffee trees source-sink manipulation alters photosynthetic rates, independently of carbon metabolism, via alterations in stomatal function. New Phytologist, v. 178, n. 2, p. 348357, 2008.

DAVIS, A. P.; GOLE, T. W.; BAENA, S.; MOAT, J. The impact of climate change on indigenous Arabica coffee (Coffea arabica): predicting future trends and identifying priorities. PLoS ONE, v. 7, n. 11, e47981, 2012.

DUAN, W.; FAN, P. G.; WANG, L. J.; LI, W. D.; YAN, S. T.; LI, S. H. Photosynthetic response to low sink demand after fruit removal in relation to photoinhibition and photoprotection in peach trees. Tree Physiology, v. 28, n. 1, p. 123-132, 2008.

ECHAVARRIA, J. J.; OROZCO, L.; TELLEZ, C. La función de producción de café. Ensayos de Economía Cafetera, v. 5, n. 8, p. 58-84, 1993.

FEDERACIÓN NACIONAL DE CAFETEROS DE COLOMBIA (FNC). Atlas cafetero de Colombia. Bogota: Imprenta Nacional de Colombia, 2017.

FRANCK, N.; VAAST, P.; GENARD, M.; DAUZAT, J. Soluble sugars mediate sink feedback down-regulation of leaf photosynthesis in field-grown Coffea arabica. Tree Physiology, v. 26, n. 4, p. 517-525, 2006.

HUNT, R. Basic growth analysis. Dordrecht: Springer, 1990.

LAVIOLA, B. G.; MARTINEZ, H. E. P.; SOUZA, R. B. de; SALOMÃO, L. C. C.; CRUZ, C. D. Macronutrient accumulation in coffee fruits at Brazilian Zona da Mata conditions. Journal of Plant Nutrition, v. 32, n. 6, p. 980995, 2009.

MORAIS, L. E.; CAVATTE, P. C.; DETMANN, K. C.; SANGLARD, L. M. V. P.; RONCHI, C. P.; DAMATTA,
F. M. Source strength increases with the increasing precociousness of fruit maturation in field-grown clones of conilon coffee (Coffea canephora) trees. Trees, v. 26, n. 4, p. 1397-1402, 2012.

RIAÑO, N. M.; ARCILA, J.; JARAMILLO, A.; CHAVES, B. Acumulación de materia seca y extracción de nutrimentos por Coffea arabica L. cv Colombia en tres localidades de la Zona Cafetera Central. Revista Cenicafé, v. 55, n. 4 , p. 265-276, 2004.

RIVAS, F.; GRAVINA, A.; AGUSTI, M. Girdling effects on fruit set and quantum yield efficiency of PSII in two citrus cultivars. Tree Physiology, v. 27, n. 4, p. 527-535, 2007.

RONCHI, C. P.; DAMATTA, F. M.; BATISTA, K. D.; MORAES, G. A. B. K.; LOUREIRO, M. E.; DUCATTI, C. Growth and photosynthetic down-regulation in Coffea arabica in response to restricted root volume. Functional Plant Biology, v. 33, n. 11, p. 1013-1023, 2006.

SADEGHIAN, S. Manejo integrado de nutrientes para una caficultura sostenible. Suelos Ecuatoriales, v. 44, n. 2 , p. 74-89, 2014.

SAS INSTITUTE. SAS/STAT ${ }^{\circledR} 15.1$ user's guide. Cary: SAS Institute, 2018.

SMIT, T. G.; TAYLOR, N. J.; MIDGLEY, S. J. The seasonal regulation of gas exchange and water relations of field grown macadamia. Scientia Horticulturae, v. 267, e109346, 2020.

UNIGARRO, C. A.; HERNÁNDEZ, J. D.; MONTOYA, E. C.; MEDINA, R. D.; IBARRA, L. N.; CARMONA, C. Y.; FLÓREZ, C. P. Estimation of leaf area in coffee leaves (Coffea arabica L.) of the Castillo ${ }^{\circledR}$ variety. Bragantia, v. 74, n. 4, p. 412-416, 2015.

URBAN, L.; LÉCHAUDEL, M.; LU, P. Effect of fruit load and girdling on leaf photosynthesis in Mangifera indica L. Journal of Experimental Botany, v. 55, n. 405, p. 2075-2085, 2004.

VAAST, P.; ANGRAND, J.; FRANCK, N.; DAUZAT, J.; GENARD, M. Fruit load and branch ring-barking affect carbon allocation and photosynthesis of leaf and fruit of Coffea arabica in the field. Tree Physiology, v. 25, n. 6, p. 753-760, 2005.

VAAST, P.; BERTRAND, B.; PERRIOT, J.-J.; GUYOT, B.; GÉNARD, M. Fruit thinning and shade improve bean characteristics and beverage quality of coffee (Coffea arabica L.) under optimal conditions. Journal of the Science of Food and Agriculture, v. 86, n. 2, p. 197-204, 2006.

VAAST, P.; DAUZAT, J.; GÉNARD, M. Modeling the effects of fruit load, shade and plant water status on coffee 
berry growth and carbon partitioning at the branch level. Acta Horticulturae, v. 584, n. 1, p. 57-62, 2002.

VALENCIA, A. Relación entre el índice de área foliar y la productividad del cafeto. Revista Cenicafé, v. 24, n. 1, p. 79-89, 1973.

ZHANG, Z. X.; CAI, Z. Q.; LIU, G. Z.; WANG, H.; HUANG, L.; CAI, C. T. Effects of fertilization on the growth, photosynthesis, and biomass accumulation in juvenile plants of three coffee (Coffea arabica L.) cultivars. Photosynthetica, v. 55, n. 1, p. 134-143, 2017.

ZHEN, J.; TRIPLER, E.; PEVZNER, S.; LAZAROVITCH, N. Impact of fruiting on gas exchange, water fluxes and frond development in irrigated date palms. Scientia Horticulturae, v. 244, n. 1, p. 234-241, 2019. 